\title{
PERFORMANCE OF HOLSTEIN-ZEBU COWS UNDER PARTIAL REPLACEMENT OF CORN BY COFFEE HULLS
}

\author{
Anamaria Almeida Costa Tavares ${ }^{1}$; Marcos Neves Pereira ${ }^{1 *}$; Marcelo Rodrigo Tavares²; Márcio \\ Luiz Chaves $^{1}$ \\ ${ }^{1}$ UFLA - Depto. de Zootecnia, C.P. 3037 - 37200-000 - Lavras, MG - Brasil. \\ ${ }^{2}$ Unifenas - Clínica de Fisioterapia, R. Geraldo Freitas Costa 120 - 37130-000 - Alfenas, MG - Brasil. \\ *Corresponding author <mpereira@ufla.br>
}

\begin{abstract}
Replacement of corn by citrus pulp or coffee hulls explores the potential of dairy cows to digest fiber-rich feedstuffs. However, for the State of Minas Gerais, Brazil, replacing citrus pulp by coffee hulls may reduce milk production costs, since citrus pulp needs to be imported from another state, while coffee hulls are highly available at essentially no cost. The objective of this experiment was to evaluate the performance of crossbred cows fed concentrates containing 25\% coffee hulls (Coffee) or $25 \%$ citrus pulp (Pulp) as a replacement for ground corn grain (Corn; $47.4 \%$ in the concentrate). Forty-two cows were blocked based on milk yield and allocated to one of the three treatments for 56 days, following a 14-day standardization period. Concentrates were fed twice a day during the milking routine, $1 \mathrm{~kg}$ to each $2.5 \mathrm{~kg}$ of the average milk yield for the block, determined at the end of the standardization period. The daily $3.5 \%$ fat-corrected milk yield was $7.5 \mathrm{~kg}$ for Corn, $7.9 \mathrm{~kg}$ for Pulp and $6.2 \mathrm{~kg}$ for Coffee $(P<0.01)$. Cows consuming coffee hulls had greater body weight loss $(P=0.03)$. Feed orts during milking amounted to $30 \%$ of the concentrate offered in Coffee, greater than the other treatments throughout the experimental period $(P<0.01)$. The mean daily intake of coffee hulls was 575 grams. The frequency of cows reluctant to enter the milking parlor yoke was $10 \%$ for Coffee and $1 \%$ for the other two treatments $(P<0.01)$. There was no detectable effect of coffee hulls on cow temperament and frequency of defecation during milking, as well as on somatic cell count $(P>0.26)$. The Pulp concentrate provided the highest financial efficiency, while Coffee was the least efficient $(P<0.01)$. These data suggest that the potential of use of coffee hulls is low when added at rates equal to or greater than $25 \%$ of the concentrate offered during the milking routine.
\end{abstract}

Key words: Brazil, temperament, citrus pulp, crossbred cow, byproduct

\section{DESEMPENHO DE VACAS HOLANDÊS-ZEBU SOB SUBSTITUIÇÃO PARCIAL DE MILHO POR CASCA DE CAFÉ}

RESUMO: A substituição de milho por polpa de citros ou casca de café explora o potencial da vaca leiteira de digerir alimentos ricos em fibra. Entretanto, para o Estado de Minas Gerais, Brasil, a substituição de polpa cítrica por casca de café pode reduzir o custo de produção do leite, pois a polpa requer importação de outro estado, enquanto a casca de café existe em alta disponibilidade e a preço praticamente nulo. $\mathrm{O}$ objetivo deste experimento foi avaliar o desempenho de vacas mestiças alimentadas com concentrados contendo $25 \%$ de casca de café (Café) ou 25\% de polpa de citros (Polpa) em substituição ao milho em grão moído (Milho; 47,4\% do concentrado). Quarenta e duas vacas foram divididas em 14 blocos por produção de leite e alocadas a um dos três tratamentos por 56 dias, após um período de padronização de 14 dias. Os concentrados foram fornecidos duas vezes ao dia no momento das ordenhas, $1 \mathrm{~kg}$ para cada 2,5 kg da produção média de leite do bloco mensurada no final do período de padronização. A produção diária de leite corrigida para 3,5\% de gordura foi 7,5 kg no Milho, 7,9 kg no Polpa e 6,2 kg no Café $(P<0.01)$. As vacas consumindo casca de café tiveram maior perda de peso vivo $(P=0.03)$. A sobra de cocho no momento da ordenha foi $30 \%$ da quantidade oferecida no Café, mais alta que nos outros tratamentos ao longo de todo o período experimental $(P<0.01)$. O consumo diário médio de casca de café foi 575 gramas. A frequiência de vacas relutando em entrar no canzil no momento da ordenha foi $10 \%$ no Café e $1 \%$ nos outros dois tratamentos $(P<0.01)$. Não foi detectado efeito da casca de café sobre o temperamento e a freqüência de defecação no momento da ordenha e sobre a contagem de células somáticas $(P>0.26)$. $O$ concentrado Polpa foi o de maior eficiência financeira e o Café o menos eficiente $(P<0.01)$. Estes dados sugerem que é baixo o potencial de utilização da casca de café em inclusões iguais ou superiores a $25 \%$ do concentrado oferecido no momento da ordenha.

Palavras-chave: Brasil, temperamento, polpa de citros, girolando, subproduto 


\section{INTRODUCTION}

The ability ruminants have to digest fiber-rich feeds symbiotically makes these animals capable of consuming diets formulated with non-forage fiber sources (NFFS), byproducts of plants used for human consumption (Armentano \& Pereira, 1997). The State of Minas Gerais yields about $50 \%$ of the coffee (SPA, 2002a) and $30 \%$ of the milk produced in Brazil (SPA, 2002b). Making coffee hulls viable as a feed for lactating cows would be a complementary practice between the coffee and dairy industries in this state.

There is a scarcity of published data on the use of coffee hulls as feed for dairy cows. Barcelos et al. (1996) evaluated the performance of Holstein cows fed concentrates in which $0 \%$ to $30 \%$ of the corn was replaced by ground coffee hulls. The daily intake of coffee hulls ranged between 0.6 and $1.7 \mathrm{~kg}$. For these cows, with a daily milk yield of $16.9 \mathrm{~kg}$, the treatment containing $30 \%$ coffee hulls yielded $1.4 \mathrm{~kg}$ less milk per day than the treatment containing $0 \%$ hulls, a non-significant difference.

Pelletized citrus pulp (Citrus spp.) is a byproduct from orange juice manufacturing and represents about $50 \%$ of the fruit (ABECITRUS, 2002). It is used as an energetic concentrate in ruminant feeding, and has nutritional value for lactation similar to corn (Andrade, 2002; Assis et al., 2000; Nussio et al., 2000). The State of São Paulo yields about $80 \%$ of all Brazilian oranges, and Minas Gerais has been an importer of São Paulo's citrus pulp to be used as cattle feed. Although using citrus pulp is an effective way to explore the NFFS ingestion potential of dairy cows, the possibility of using coffee hulls as a replacement for citrus pulp would make the State of Minas Gerais a more efficient milk producer, by avoiding the cost of transportation of this byproduct into the state.

The objective of this work was to evaluate the performance of dairy Holstein-Zebu cows fed concentrates containing $25 \%$ coffee hulls or $25 \%$ citrus pulp as replacements for dry ground corn grain. Both citrus pulp and corn were used as controls to test the viability of coffee hulls as feed for low-producing dairy cows fed concentrates during the milking routine.

\section{MATERIAL AND METHODS}

Forty-two crossbred lactating Holstein-Zebu cows, reared in Divisa Nova, MG, Brazil, were used in an experiment from $07 / 21 / 2000$ to $09 / 30 / 2000$, during the dry season of the year. All animals received $4 \mathrm{~kg}$ of the Standard concentrate during a pre-experimental standardization period of 14 days (Table 1). The mean daily milk yield at the end of the standardization period was $8.0 \mathrm{~kg}$, with a standard deviation of $3.0 \mathrm{~kg}$; the minimum daily
Table 1 - Ingredient composition of concentrates Corn, Pulp, Coffee, and Standard (\% of as fed).

\begin{tabular}{lrrrc}
\hline & Corn & Pulp & Coffee & Standard \\
\hline Corn & 47.4 & 22.4 & 22.4 & 15.0 \\
Citrus pulp & & 25.0 & & 30.0 \\
Coffee hulls & & & 25.0 & 10.0 \\
Soybean meal & 14.6 & 14.6 & 14.6 & 18.5 \\
Whole cottonseed & 30.0 & 30.0 & 30.0 & 20.0 \\
Urea & 3.0 & 3.0 & 3.0 & 2.5 \\
Limestone & 2.5 & 2.5 & 2.5 & \\
Mineral mix & 2.5 & 2.5 & 2.5 & 2.5 \\
NaCl & & & & 1.5 \\
\hline US\$ kg-2 & 0.1341 & 0.1236 & 0.1085 & 0.1150 \\
\hline
\end{tabular}

${ }^{1}$ Mineral mix $\left(\mathrm{kg}^{-1}\right)$ : calcium, $230 \mathrm{~g}$; phosphorus, $90 \mathrm{~g}$; magnesium, 20 g; sulfur, 15 g; sodium, 240 g; chlorine, 240 g; fluorine, 0.9 g; copper, $700 \mathrm{mg}$; zinc, 2,700 mg; manganese, 1,250 mg; iron, 2,000 mg; iodine, 80 mg; cobalt, 100 mg; selenium, 20 mg; Vit A, 200,000 IU; Vit D3, 60,000 IU; Vit E, 60 IU.

${ }^{2}$ Cost based on the average price of ingredients in the year 2000, when the experiment was carried out. It assumes coffee hulls have a zero cost. The exchange rate between the Brazilian Real and the US dollar during the experimental period was 1.82 .

yield was $3.5 \mathrm{~kg}$ and the maximum was $14.5 \mathrm{~kg}$. These yields are typical for crossbred cows in mid to late lactation and under a low daily nutrient input.

Milk yield during the four consecutive milkings on days 13 and 14 of the standardization period were used as a criterion to distribute cows through 14 blocks of 3 animals, characterizing a randomized complete block design. Of the 42 cows, 33 had a calf suckling and 9 were milked in the absence of calves. Blocking by milk yield was a secondary criterion in relation to the presence of the calf during milking. Therefore, 11 blocks were formed with cows having calf sucklings and 3 blocks with cows without a calf. Within each block, animals were allocated at random to one of three concentrates on day 1 of the comparison period, receiving each treatment continuously for 56 days. Concentrates were formulated by adding $25 \%$ coffee hulls (Coffee) or citrus pulp (Pulp) as partial replacement for corn in the corn concentrate (Table 1).

The coffee hulls comprised all material resulting from coffee processing, including the skin, the pulp, and the hull (parchment), and were not ground before being mixed with other feeds. Citrus pulp was used in the form of pellets. Concentrates were mixed twice throughout the experimental period.

The concentrates were supplied during milking time, twice a day, in a feeding trough with yokes for individual restraining. The concentrate was placed in the trough before introducing the animal into the parlor. Animals of the same block received $1 \mathrm{~kg}$ concentrate per each $2.5 \mathrm{~kg}$ of the average milk yield in the block, as deter- 
mined by the milk yield on days 13 and 14 of the standardization period. The same amount of concentrate was supplied to each animal throughout the 56-day comparison period. During the entire experiment, the animals were fed as a group, receiving $20 \mathrm{~kg}$ of sugarcane and $200 \mathrm{~g}$ of urea between the two daily milking operations, and had continuous ad libitum access to water and minerals (1:1, $\mathrm{NaCl}$ :mineral mix). The animals were allowed access to pasture (Brachiaria mutica) at night.

Concentrates were sampled every time they were mixed, and composite samples were formed for laboratory analysis. The two coffee hull batches used in the experiment were also sampled and a composite sample formed as well. A sugarcane sample was collected at the end of the standardization period and at each week of the comparison period, forage samples were stored at $-20^{\circ} \mathrm{C}$. These samples were pre-dried in a ventilated oven at $55^{\circ} \mathrm{C}$ for 72 hours and ground with a Wiley-type mill through a 1-mm mesh sieve. The weekly sugarcane samples and the composite samples of each concentrate and coffee hulls were analyzed for dry matter (DM), crude protein (CP), and ether extract (EE), according to AOAC (1990), while ash-free neutral detergent fiber (NDF) and acid detergent fiber (ADF) were determined according to Van Soest et al. (1991).

Milk yield was determined during four consecutive milkings on days 13 and 14 of the standardization period and at seven-day intervals, starting on day 7 , during the comparison period. A composite sample of the daily milk produced during each week was prepared proportionally to the volume of each milking, stored in flasks containing potassium dichromate capsules, and analyzed for fat by Gerber's butyrometric method (Brasil, 1981), for crude protein by the Kjeldahl method (AOAC, 1990), and for somatic cell count (SCC) by infrared spectroscopy (Somacount ${ }^{\circledR} 300$, Bentley Instruments, Chaska, MN, USA). The daily protein and fat yield was calculated weekly, and the 3.5\% fat-corrected milk yield (Milk $3.5 \% \mathrm{~F})$ was calculated by the following equation: $(0.432$ $\times$ Milk yield $)+(16.23 \times$ Fat yield $)$. The natural logarithm of the SCC was obtained (Linear SCC). A linear SCC value above 4 was used as an indicator of mastitis.

The weight of concentrate orts in the feeding trough was determined at four consecutive milkings at the end of each week throughout the comparison period. The average weekly orts in the trough was expressed as a percentage of the concentrate supplied to each animal. This data was not collected at the end of the standardization period. Concentrate intake was obtained by subtracting orts from the amount supplied. Feed conversion was calculated by dividing milk yield by concentrate intake within the same week. Financial efficiency was calculated by subtracting the daily cost of concentrate from gross milk income. Gross milk income was obtained by multiplying weekly milk yield by milk prices per liter, US\$
0.22 (EF22) and US\$ 0.14 (EF14). Concentrate cost was calculated based on the mean price of feeds from January to December 2000, and a zero value was attributed to coffee hulls (Table 1 ).

The reluctance of the animals to enter the yoke during milking was evaluated as an indicator of concentrate acceptance. Reluctance was evaluated at four consecutive milkings at the end of each week throughout the comparison period. The criterion used to evaluate reluctance was that two or three people were required to introduce the animal into the yoke, which did not occur during the regular farm routine.

Possible effects of caffeine on cow temperament were evaluated using a temperament scoring system in a scale from 1 to 4 (calm to agitated) (Dickson et al., 1970). Temperament was evaluated at the end of the standardization period and at seven-day intervals along the comparison period. Defecation frequency at milking time was also evaluated as a temperament indicator. Defecation during milking was evaluated during one milking at the end of the standardization period and at seven-day intervals during the comparison period.

Body condition was evaluated visually on a scale from 1 to 5 (thin to fat) according to Wildman et al. (1982), based on digital camera cow pictures taken in a caudal-rostral direction at the end of the standardization period and in weeks 4 and 8 of the comparison period. Body weight was determined at the end of the standardization period and in weeks 4 and 8 of the comparison period. Weight was determined after the morning milking, randomly within blocks. Daily weight gain was calculated by linear regression of the body weight values measured in the last week of the standardization period and in weeks 4 and 8 of the comparison period.

The weekly-collected data (milk, fat, and protein yields; Milk 3.5\%F; fat and protein percentages; Linear SCC; body weight; body condition; temperament; concentrate intake; concentrate orts; feed conversion; and financial efficiency) were analyzed using the repeated measures approach of the SAS MIXED procedure (Littel et al., 1996). The covariance structure used was the one with the highest value for the Akaike's information criterion. The covariance structures considered were: compound symmetric, autoregressive order one, and unstructured.

The following model was used:

$$
\mathrm{Y}_{\mathrm{ijk}}=\mu+\mathrm{CV}+\mathrm{B}_{\mathrm{i}}+\mathrm{C}_{\mathrm{j}}+\mathrm{S}_{\mathrm{k}}+\mathrm{CS}_{1}+\mathrm{E}_{\mathrm{ijk}}
$$

where: $\mu=$ overall mean; $\mathrm{CV}=$ covariate (measurement of the same variable in the last week of the standardization period); $\mathrm{B}_{\mathrm{i}}=$ block effect ( $\mathrm{i}=1$ to 14 ); $\mathrm{C}_{\mathrm{j}}=$ concentrate effect $\left(\mathrm{j}=\right.$ Coffee, Corn, Pulp); $\mathrm{S}_{\mathrm{k}}=$ week effect $(\mathrm{k}$ $=1$ to 8$) ; \mathrm{CS}_{\mathrm{jk}}=$ interaction between concentrate and week; $E_{\mathrm{ijk}}=$ residual error. 
The mean square for the effect of cow nested within treatment was used as the error term to test the concentrate effect. A model containing only fixed block and treatment effects was used for the variable daily weight gain. The degrees of freedom for concentrate were partitioned into two single degree of freedom orthogonal contrasts: Coffee vs Corn and Coffee vs Pulp. Defecation frequency during milking, reluctance in entering the yoke, and incidence of mastitis were tested using the Chi-square test of the FREQ procedure (SAS, 1985).

\section{RESULTS AND DISCUSSION}

The coffee hulls used in this experiment can be considered as a representative sample of this feedstuff, its nutritional composition being similar to the average value of published references (Barcelos, 2000; Barcelos et al., 1996; 1997a; 1997b; Ribeiro Filho, 1998; Teixeira, 1999) (Table 2). The sugarcane had low nutritional value, judging by the high NDF concentration in the DM (Table 2 ). Well-grown and managed sugarcane may have fiber content similar to good-quality corn silage, around 45\% of DM (Corrêa et al., 2003). This fact, in association with a likely low nutritional value of the dry season grazed Brachiaria, probably contributed to the low milk yield of the animals in this experiment (Table 3). These management conditions, although not desirable, are typical of farms where crossbred Holstein-Zebu cows are raised. The inferences of this experiment are to be made exclusively to cows of low yield potential consuming forages of low nutritional value.

Replacing corn by coffee hulls decreased milk and solids yield in these low-yielding cows, while citrus pulp had a nutritional value apparently similar to corn (Table 3). A milk yield reduction was already observed in the first week of treatment application and was maintained along the entire eight-week comparison period (Figure 1). Dietary coffee hull additions lower than those used in this experiment seem to be required if this feed is to be used for low-yielding dairy cows, without undesirable negative effects on animal performance.

Increased dietary NDF content obtained by replacing corn by coffee hulls did not result in increased milk fat percentage (Table 3). A positive response in milk fat percentage to an increase in dietary NDF from concentrates is expected when the concentration of fiber in the basal

Table 2 - Nutrient composition of concentrates Corn, Pulp, and Coffee, in coffee hulls and sugarcane. Values are expressed as \% dry matter, except dry matter, which corresponds to \% as fed.

\begin{tabular}{lccccc}
\hline & Coffee hulls & Sugarcane $^{1}$ & Corn & Pulp & Coffee \\
\hline Dry matter & 88.7 & $32.2 \pm 2.50$ & 89.8 & 88.6 & 91.0 \\
Crude protein & 9.2 & $2.9 \pm 0.27$ & 24.6 & 27.4 & 25.1 \\
Neutral detergent fiber & 56.5 & $57.3 \pm 2.74$ & 25.8 & 26.6 & 39.1 \\
Acid detergent fiber & 45.0 & $34.1 \pm 1.85$ & 17.3 & 9.6 & 9.1 \\
Ether extract & 5.5 & $2.2 \pm 0.67$ & 28.0 & 11.2 \\
\hline
\end{tabular}

${ }^{1}$ Mean and standard deviation of nine sugarcane samples collected weekly throughout the experimental period.

Table 3 - Performance of crossbred Holstein-Zebu cows receiving treatments Corn, Pulp, or Coffee.

\begin{tabular}{|c|c|c|c|c|c|c|c|c|c|}
\hline & Corn & Pulp & Coffee & $\mathrm{SEM}^{3}$ & Conc $^{4}$ & $\mathrm{Wk}^{4}$ & Conc $* \mathrm{Wk}^{4}$ & Coffee vs Pulp ${ }^{4}$ & Coffee vs Corn ${ }^{4}$ \\
\hline Milk $\left(\mathrm{kg} \mathrm{d}^{-1}\right)$ & 7.3 & 7.7 & 6.3 & 0.3 & 0.02 & $<0.01$ & 0.05 & $<0.01$ & 0.04 \\
\hline Milk 3.5\%F $\left(\mathrm{kg} \mathrm{d}^{-1}\right)$ & 7.5 & 7.9 & 6.2 & 0.3 & $<0.01$ & 0.11 & 0.04 & $<0.01$ & 0.01 \\
\hline Fat $(\%)$ & 3.83 & 3.75 & 3.68 & 0.09 & 0.46 & $<0.001$ & 0.18 & 0.58 & 0.22 \\
\hline Protein $(\%)$ & 3.47 & 3.46 & 3.52 & 0.06 & 0.72 & $<0.001$ & 0.74 & 0.46 & 0.52 \\
\hline Fat $\left(\mathrm{kg} \mathrm{d}^{-1}\right)$ & 0.27 & 0.28 & 0.21 & 0.01 & $<0.01$ & 0.01 & 0.07 & $<0.01$ & 0.01 \\
\hline Protein $\left(\mathrm{kg} \mathrm{d}^{-1}\right)$ & 0.25 & 0.26 & 0.21 & 0.01 & 0.02 & 0.26 & 0.63 & $<0.01$ & 0.03 \\
\hline Body condition $(1 \text { to } 5)^{1}$ & 2.80 & 2.81 & 2.83 & 0.09 & 0.96 & 0.99 & 0.99 & 0.87 & 0.79 \\
\hline Body weight (kg) & 491 & 504 & 478 & 5.8 & 0.02 & 0.08 & 0.87 & $<0.01$ & 0.12 \\
\hline Weight gain $\left(\mathrm{g} \mathrm{d}^{-1}\right)$ & -385 & -147 & -567 & 101 & 0.03 & & & $<0.01$ & 0.21 \\
\hline Linear $\mathrm{SCC}^{2}$ & 4.03 & 4.40 & 4.45 & 0.26 & 0.46 & 0.03 & 0.45 & 0.89 & 0.25 \\
\hline
\end{tabular}

${ }^{1}$ Body condition score. 1 to 5 , thin to fat.

${ }^{2}$ Linear SCC $=$ Linear somatic cell count

${ }^{3} \mathrm{SEM}=$ Standard error of the mean

${ }^{4} \mathrm{P}$ for the effects: Conc $=$ Concentrate. $\mathrm{Wk}=$ Week. Conc $*$ Wk $=$ Interaction between Conc and Wk. Coffee vs Pulp $=$ Coffee vs Pulp contrast. Coffee vs Corn $=$ Coffee vs Corn contrast. 
Table 4 - Temperament, concentrate intake, feed conversion and financial efficiency of crossbred Holstein-Zebu cows receiving treatments Corn, Pulp, or Coffee.

\begin{tabular}{lccccccccc}
\hline & Corn & Pulp & Coffee & SEM $^{5}$ & Conc $^{6}$ & Wk $^{6}$ & Conc $^{*}$ Wk $^{6}$ & Coffee vs Pulp $^{6}$ & Coffee vs Corn $^{6}$ \\
\hline Temperament $(1-4)^{1}$ & 2.08 & 2.14 & 2.07 & 0.04 & 0.47 & 0.39 & 0.40 & 0.25 & 0.84 \\
Concentrate intake $\left(\mathrm{kg} \mathrm{d}^{-1}\right)$ & 3.4 & 2.8 & 2.3 & 0.15 & $<0.001$ & 0.01 & $<0.01$ & 0.02 & $<0.001$ \\
Orts $(\%$ of offered feed) & 2.2 & 11.8 & 30.3 & 3.12 & $<0.001$ & 0.03 & 0.02 & $<0.001$ & $<0.001$ \\
Feed conversion $\left(\mathrm{kg} \mathrm{kg}^{-1}\right)^{3}$ & 2.22 & 2.47 & 2.87 & 0.19 & 0.06 & $<0.01$ & $<0.01$ & 0.15 & 0.02 \\
EF22 $\left(\mathrm{US} \$ \mathrm{~d}^{-1}\right)^{4}$ & 1.11 & 1.27 & 0.98 & 0.08 & 0.05 & $<0.001$ & 0.09 & 0.02 & 0.25 \\
EF14 (US $\left.\$ \mathrm{~d}^{-1}\right)^{4}$ & 0.52 & 0.64 & 0.47 & 0.05 & 0.08 & $<0.001$ & 0.09 & 0.03 & 0.49 \\
\hline
\end{tabular}

${ }^{1}$ Temperament $=1$ to 4 , docile to recalcitrant.

${ }^{2}$ Concentrate orts at milking time $=($ Concentrate orts $/$ Concentrate offered $) \times 100$.

${ }^{3}$ Feed conversion $=$ Milk yield $/$ Concentrate intake.

${ }^{4}$ EF22 and EF14= Financial efficiency at a milk price of US\$ 0.22/L and US\$ 0.14/L = Gross income - Cost of concentrate. The exchange rate between the Brazilian Real and the US dollar during the experimental period was 1.82 .

${ }^{5} \mathrm{SEM}=$ Standard error of the mean

${ }^{6} \mathrm{P}$ for the effects: Conc $=$ Concentrate. $\mathrm{Wk}=$ Week. Conc $*$ Wk $=$ Interaction between Conc and Wk. Coffee vs Pulp $=$ Coffee vs Pulp contrast. Coffee vs Corn $=$ Coffee vs Corn contrast.

diet is originally low (Armentano \& Pereira, 1997). The high NDF percentage of the consumed diet and the low yield potential of the animals may have contributed to a lack of response in fat content to starch replacement with NDF from concentrates in this experiment.

There was a body weight reduction in the Coffee treatment, which is an indicator of reduced daily weight gain, since body weight values were adjusted for the covariate measurement obtained at the end of the standardization period (Table 3). Daily weight gain was negative, as calculated by linear regression of the three weight data for each cow along the experiment. The input of nutrients was apparently below animals requirements in all treatments. This body weight variation pattern seems to be representative of milk production systems using crossbred animals with access to pasture during the dry season of the year in Southeastern Brazil. The Coffee concentrate resulted in greater daily body weight loss of the animals. However, the difference in daily weight change was apparently not sufficient to induce a concomitant detectable change in body condition. A milk yield reduction of approximately $15 \%$ in the Coffee treatment, as compared to the control treatments Corn and Pulp, was not followed by a simultaneous decrease in body condition (Table 3).

The intake of the Coffee concentrate was the lowest (Table 4). Since feed conversion was calculated by the ratio of milk yield to concentrate intake, the Coffee concentrate had the highest feed conversion efficiency. Orts at milking time was consistently higher in this treatment (Figure 2), and the frequency of cows reluctant to enter the yoke was also the greatest (Table 5). A higher orts value was also observed for the concentrate Pulp in relation to Corn (Table 4), probably associated with the fact that the citrus pulp ingredient was pelletized, which may have made it difficult for the animals to completely consume the amount offered in the available milking time.

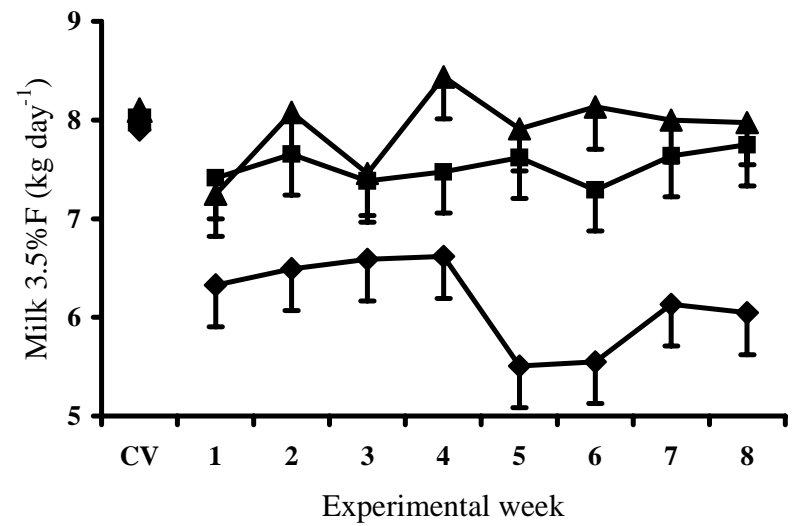

Figure 1 - Fat-corrected milk yield (Milk 3.5\%F) in cows receiving treatments Corn $(\boldsymbol{\nabla})$, Pulp $(\boldsymbol{\Delta})$, or Coffee $(\bullet)$. CV $=$ Milk 3.5\%F at the end of standardization period. $P=0.04$ for the interaction between concentrate and experimental week.

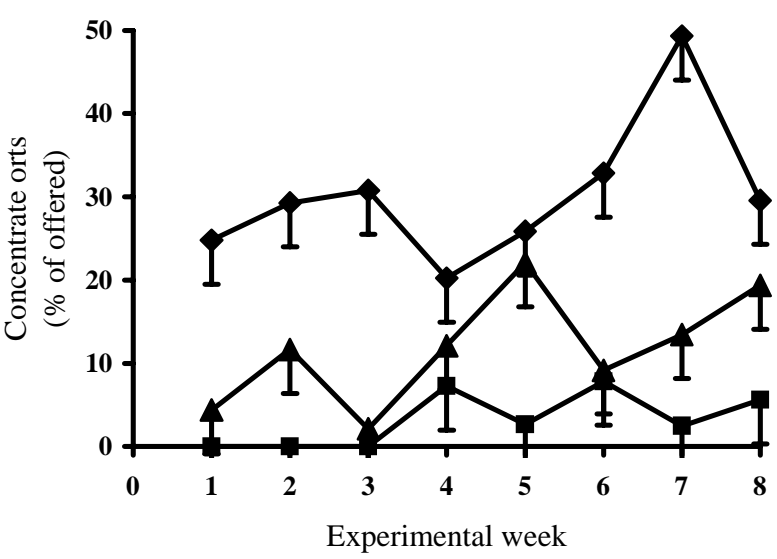

Figure 2 - Concentrate orts left in the feeding trough during milking time for cows receiving treatments Corn ( $\mathbf{\square})$, Pulp $(\boldsymbol{\Delta})$, or Coffee $(\bullet) . P=0.02$ for the interaction between concentrate and experimental week. 
Table 5 - Frequency of animals with a Linear SCC above 4, presenting defecation at milking time, and reluctant to enter the yoke in treatments Corn, Pulp, or Coffee.

\begin{tabular}{|c|c|c|c|c|}
\hline & Corn & Pulp & Coffee & Chi-square $P$ \\
\hline Observations/week & 14 & 14 & 14 & \\
\hline $\begin{array}{l}\text { Experimental } \\
\text { weeks }\end{array}$ & 8 & 8 & 8 & \\
\hline Linear SCC $>4$ & 64.3 & 53.6 & 59.8 & 0.26 \\
\hline $\begin{array}{l}\text { Defecation at } \\
\text { milking }\end{array}$ & 17.0 & 11.6 & 16.1 & 0.47 \\
\hline $\begin{array}{l}\text { Reluctance to enter } \\
\text { the yoke }\end{array}$ & 0.9 & 0.9 & 9.8 & $<0.01$ \\
\hline
\end{tabular}

The mechanisms by which Pulp and Coffee concentrate orts occurred were apparently different, since the frequency of reluctance to enter the yoke was not high for the Pulp concentrate (Table 5). There have been reports of sharp declines in dry matter intake of calves and steers when coffee pulp replaced cottonseed hulls in dietary inclusions above $20 \%$ of the concentrate fresh matter supplied (Vargas et al., 1977; 1982).

The incorporation of coffee hulls into ruminant diets may be more effectively done in farms that use the complete diet as a feeding system for the herd, since in such cases the potentially intake-reducing characteristics of each feed would be diluted per mouthful, after being mixed with other dietary ingredients (Coppock, 1977). The addition of coffee hulls to concentrates supplied to animals at milking time and not mixed with forages seems to require inclusion levels below $25 \%$ of the concentrate mix. Assuming constancy in the ingredient composition of the supplied concentrates and feed orts, the daily intake of coffee hulls was only 575 g per animal (Tables 1 and 4).

Assuming that the mean tannin content in coffee hulls is about 2.18\% (Vargas et al., 1977; 1982; Barcelos, 2000; Barcelos et al., 1996; 1997a; 1997b), the daily intake of tannin in this experiment was estimated to be around $12.5 \mathrm{~g}$. This value is lower than the daily tannin intake suggested as detrimental to the digestion of carbohydrates in the rumen, something around $440 \mathrm{~g}$ in cows with a daily dry matter intake of about $11 \mathrm{~kg}$ (Broderick et al., 1991). The role of tannin as an intake reducing factor in the Coffee treatment cannot be accertained by this experiment, and probably would require feeding trials using methodologies capable of isolating the effect of these compounds from other coffee hull characteristics as a feedstuff.

Since caffeine has a stimulating effect over the whole metabolism, it can potentially impact animal behavior (Nehlig et al., 1992), particularly undesirable because it may make milking practices more difficult. No coffee hull effect was detected on cow temperament, as evaluated by the scoring system (Table 4). No effect of the concentrate was also observed on defecation frequency at milking time (Table 5). Greater stress could also negatively affect the immune system and increase the incidence of mastitis. No treatment effect was detected on the frequency of subclinical mastitis (Table 5) and on Linear SCC (Table 3). The mean caffeine content in coffee hulls or pulp is around $0.84 \%$ of DM (Bressani et al., 1972; Vargas et al., 1977; 1982; Barcelos, 2000; Barcelos et al., 1996; 1997a; 1997b; Ribeiro Filho, 1998). Assuming this value is representative of the coffee hulls used in this experiment, the estimated daily intake of caffeine was around $4.6 \mathrm{~g}$. Degraves et al. (1995) reported that the intravenous administration of $8 \mathrm{mg}$ caffeine per $\mathrm{kg}$ of body weight was not sufficient to induce any behavioral change in dairy cows. The caffeine intake in this experiment, estimated to be around $9.4 \mathrm{mg} \mathrm{kg}^{-1}$ body weight, was apparently unable to induce behavioral disorders on these cows. No data are available on the temperament of animals with greater taurine genetic makeup, more docile than the crossbred Holstein-Zebu animals used in this study (Madalena et al., 1989).

At year 2000 prices, the period when the experiment was carried out, the addition of $25 \%$ citrus pulp or coffee hulls as replacements for corn reduced the cost per $\mathrm{kg}$ of concentrate by $8 \%$ and $19 \%$, respectively (Table 1 ). If corn and citrus pulp prices were higher than those observed during that period, replacing this grain with NFFS would be even more advantageous. In this simulation, coffee hulls was assumed to have a zero cost. This condition would hold true if the production of this feed occurred at the site where animals were fed as it was produced, eliminating, as a consequence, transportation and processing costs. Simulations in this study considered that both production and use of coffee hulls for animal feeding occurred in the same farm, characterizing the analysis of a specific situation, quite typical in the southern part of the State of Minas Gerais.

Even assuming a zero cost for the coffee hull ingredient, the concentrate with the greatest financial efficiency was Pulp (Table 4). An identical forage intake among treatments was assumed to calculate financial efficiency, since the animals were not individualized at the forage trough. Although it is possible that the nature of the concentrate could affect forage intake (Nussio et al., 2000), its impact on financial efficiency should be minimal in this experiment, since the animals consumed nonfertilized pastures with a low cost per kg of dry matter in addition to $20 \mathrm{~kg}$ sugarcane, the later supplied at restricted intake per day. The greatest daily intake (Table 4) and cost per kg of the Corn concentrate eliminated the advantage of a higher daily gross income for this concentrate in relation to Coffee. The greatest feed conver- 
sion efficiency (Table 4) and the smallest cost per kg of concentrate did not compensate the decreased milk yield induced by the Coffee concentrate (Table 3). The use of citrus pulp at $58 \%$ of the corn cost was the most beneficial financially.

\section{CONCLUSIONS}

Defining a maximum daily intake or dietary content limit for the use of coffee hulls without damaging animal performance in cows varying in body weight, milk yield, and feeding system require further studies. The data herein obtained suggest that only a low potential of use exists for this feed for dairy cows receiving concentrate feedstuffs during the milking routine. Under this type of feeding management, dietary inclusions equal to or greater than $25 \%$ of the concentrate may decrease nutrient intake and performance of low-yielding dairy cows, resulting in financial loss, even assuming a zero cost for the byproduct.

\section{ACKNOWLEDGEMENTS}

To José Dalmo Vieira Costa for allowing the use of his farm and animals and for his unrestricted support.

\section{REFERENCES}

ANDRADE, G.A. Substituição do milho moído por polpa cítrica no desempenho de vacas em lactação. Lavras: UFLA, 2002. 144p. (Tese Doutorado).

ARMENTANO, L.E.; PEREIRA, M.N. Measuring the effectiveness of fiber by animal response trials. Journal of Dairy Science, v.80, p.1416-1425, 1997.

ASSIS, A.J.; CAMPOS, J.M.S.; VALADARES FILHO, S.C.; MAGALHÃES, A.L.R.; MENDES NETO, J.; ZAMPERLINI, B. Polpa de citros em dietas de vacas em lactação. I. Produção e composição de leite. In: REUNIÃO ANUAL DA SOCIEDADE BRASILEIRA DE ZOOTECNIA, 37., Viçosa, 2000. Anais. Viçosa: SBZ, 2000. 1 CD-ROM.

ASSOCIAÇÃO BRASILEIRA DE EXPORTADORES DE CÍTRICOS. Subprodutos da laranja. Disponível em: <http://www.abecitrus.com.br/ subprobr.html>. Acesso em: 19 ago. 2002.

ASSOCIATION OF OFFICIAL ANALYTICAL CHEMIST. Official methods of the Association for Official Analytical Chemist. 15.ed. Washington, 1990. v.1, 648p.

BARCELOS, A.F. Parâmetros bromatológicos, frações de carboidratos e degradabilidade in vitro da casca e da polpa de café (Coffea arábica L.) Lavras: UFLA, 2000. 96p. (Tese - Doutorado).

BARCELOS, A.F.; ANDRADE, I.F.; TIESENHAUSEN, I.M.E.V.; FERREIRA, J.J.; SETTE, R.S.; BUENO, C.F.H.; AMARAL, R.; PAIVA, P.C.A. Aproveitamento da casca de café na alimentação de novilhos confinados: Resultados do primeiro ano. Revista Brasileira de Zootecnia, v.26, p.1208-1214, 1997a.

BARCELOS, A.F.; ANDRADE, I.F.; TIESENHAUSEN, I.M.E.V.; FERREIRA, J.J.; SETTE, R.S.; BUENO, C.F.H.; AMARAL, R.; PAIVA, P.C.A. Aproveitamento da casca de café na alimentação de novilhos confinados: Resultados do segundo ano. Revista Brasileira de Zootecnia, v.26, p.1215-1221, 1997b.

BARCELOS, A.F.; ANDRADE, I.F.; TIESENHAUSEN, I.M.E.V.; FERREIRA, J.J.; SETTE, R.S.; AMARAL, R.; PAIVA, P.S.A. Aproveitamento da casca de café na alimentação de vacas em lactação. In: REUNIÃO ANUAL DA SOCIEDADE BRASILEIRA DE ZOOTECNIA, 33., Fortaleza, 1996. Anais. Fortaleza: SBZ, 1996. p.128-129.
BRASIL. Secretaria Nacional de Defesa Agropecuária. Laboratório Nacional de Referencia Animal. Métodos analíticos oficiais para controle de produtos de origem animal e seus ingredientes. II. Métodos físicos e químicos. Brasília, 1981.

BRESANI, R.; ESTRADA, E.; JARQUIN, R. Pulpa y pergamino de café. I. Conposición química y contenido de aminoácidos de la proteína de la pulpa. Turrialba, v.22, p.229-304, 1972.

BRODERICK, G.A.; WALLACE, R.J.; ORSKOV, R.J. Control of rate and extent of protein degradation. V. Methods for protecting dietary protein. C. Tannins and other inhibitory compounds. In: TSUDA, T.; SASAKI, Y.; KAWASHIMA, R. Physiological aspects of digestion and metabolism in ruminants. San Diego: Academic Press, 1991. cap.23, p.565-569.

COPPOCK, C.E. Feeding methods and grouping systems. Journal of Dairy Science, v.60, p.1327-1336, 1977.

CORRÊA, C.E.S.; PEREIRA, M.N.; OLIVEIRA, S.G.; RAMOS, M.H. Performance of Holstein cows fed sugarcane or corn silages of different grain texture. Scientia Agricola, v.60, p.621-629, 2003.

DEGRAVES, F.J.; RUFFIN, D.C.; DURAN, S.H.; SPANO, J.S.; WHATLEY, E.M.; SCHUMACHER, J.; RIDDELL, M.G. Pharmacokinetics of caffeine in lactating dairy cows. American Journal of Veterinary Research, v.56, p.619-622, 1995.

DICKSON, D.P.; BARR, G.R.; JOHNSON, L.P.; WIECKERT, D.A. Social dominance and temperament of Holstein cows. Journal of Dairy Science, v.53, p.904-907, 1970.

LITTELL, R.C.; MILLIKEN, G.A.; STROUP, W.W.; WOLFINGER, R.D. SAS $^{\circledast}$ system for mixed models. Cary: SAS Institute, 1996. 633p.

MADALENA, F.E.; TEODORO, R.L.; NOGUEIRA, J.D.; MOREIRA, D.P. Comparative performance of six Holstein-Frieisian x Guzera crossed groups in Brazil. 4. Rate of milk flow, easy of milking and temperament. Revista Brasileira de Genética, v.12, p.39-51, 1989.

NEHLIG, A.; DAVAL, J.L.; DEBRY, G. Caffeine and the central nervous system: Mechanisms of action, biochemical, metabolic and psychostimulant effects. Brain Research Reviews, v.17, p.139-170, 1992.

NUSSIO, C.B.M.; SANTOS, F.A.P.; PIRES, A.V.B.M.; ZOPOLLATTO, M.; BARNABÉ, E.C. Efeito do processamento do milho e sua substituição por polpa de citros peletizada sobre consumo de matéria seca, produção e composição de leite de vacas em lactação. In: REUNIÃO ANUAL DA SOCIEDADE BRASILEIRA DE ZOOTECNIA, 37., Viçosa, 2000. Anais. Viçosa: SBZ, 2000. 1 CD-ROM.

RIBEIRO FILHO, E. Degradabilidade in situ da matéria seca, proteína bruta, e fibra em detergente neutro da casca de café (Coffea arábica, L.) e desempenho de novilhos em fase de recria. Lavras: UFLA, 1998. 56p. (Dissertação - Mestrado).

SAS INSTITUTE. User's guide: statistics. 5.ed. Cary, NC, 1985.

SPA. Estatísticas agrícolas - Lavouras permanentes- Café. Disponível em: <http:www.agricultura.gov.br/spa/pagespa/index.ntml>. Acesso em: 19 ago. 2002a.

SPA. Produção brasileira de leite - Unidade de Federação. Disponível em: <http:www.agricultura.gov.br/spa/pagespa/ch03/3_2.xls>. Acesso em: 31 dez. 2002b.

TEIXEIRA, M.N.M. Determinação da degradabilidade in situ das diferentes frações da casca do grão de três cultivares de café (Coffea arábica L.) Lavras;UFLA, 1999. (Dissertação - Mestrado).

VAN SOEST, P.J.; ROBERTSON, J.B.; LEWIS, B.A. Methods for dietary fiber, neutral detergent fiber, and nonstarch polysaccharides in relation to animal nutrition. Journal of Dairy Science, v.76, p.3583-3597, 1991.

VARGAS, E.; CABEZAS, M.T.; BRESSANI, R. Pulpa de café en la alimentación de rumiantes. I. Digestibilidad in vivo de la pulpa. Agronomia Costarricense, v.1, p.51-56, 1977.

VARGAS, E.; CABEZAS, M.T.; MURILLO, B. Efecto de altos niveles de pulpa de café deshidratada sobre el crecimiento y adaptación de novillos jóvenes. Archivos Latinoamericanos de Nutrición, v.34, p.973-989, 1982.

WILDMAN, E.E.; JONES, G.M.; WAGNER, P.E.; BOMAN, R.L.; TROUTT JR, H.F.; LESCH, T.N. A dairy cow body condition scoring system and its relationship to selected production characteristics. Journal of Dairy Science, v.65, p.495-501, 1982.

Received October 24, 2003

Accepted February 11, 2005 